\title{
Behaviour Analysis on Woman's KB Acceptor of Using Intra Uterine Device (IUD) in Keranggan Public Health Center, Setu Sub-district, Tangerang Selatan City in 2016
}

\author{
Lilis Suryani, Siti Riftifah Tri Handari \\ Faculty of Medicine and Health \\ University of Muhammadiyah Jakarta \\ Jakarta, Indonesia
}

\begin{abstract}
Family Planning Program (Keluarga Berencana/KB) is one of the the government efforts as a solutions for the problem of overcrowding, infant mortality and maternal mortality. Family planning allows individuals and couples to anticipate and attain their desired number of children and the spacing and timing of their births. Intra Uterine Device (IUD) is a contraceptive device fitted inside the uterus, which rarely use by woman. IUD is rarely use by woman because woman's prefer to use contraceptive methods which easy to buy and easy to use. The Purpose of this research is to find out what's factors associate with the use of an IUD on woman's acceptor KB In Puskesmas Keranggan, Kecamatan Setu, Tangerang Selatan City in 2016 The method of this research is quantitative analysis with cross sectional approach and sampling methods in this research is using accidental sampling. This research has been doing since Juni until August 2016 and the data is collected by using questionnaire to 152 sample. Then, Data is analyzed using Multivariat with logistic regression. The results of this research by using univariat analysis explained that $90,8 \%$ of respondents using non IUD contraceptions, Age less than 32 years (53,9\%), Has a low education background $(63,8 \%)$, Acceptors is working $(69,1 \%)$, Low economic status $(68,4 \%)$. Lack of knowledge $(51,3 \%)$, has a positive mind $(50,7 \%)$, Has a few of children $(74,3 \%)$, did not want any children again $(52,6 \%)$, Husband's support $(58,6 \%)$. Then, using multivariat factor analysis, the dominant factor that associates Woman's Acceptor KB using IUD is Attitude (Score of Exp B = 6,024). Further, Based on the results of this research, it hopes that health workers give many health informations for people to increase the couple's knowledge who wants using contraceptive methods and give them contraceptive methods education, especially Intra Uterine Devices (IUD) that they would has good knowledge about the good contraceptions methods which are safe and comfort to use.
\end{abstract}

Keywords-Attitude; Contraceptions; Family Planning; Knowledge; IUD

\section{INTRODUCTION}

Family Planning Program $(\mathrm{KB})$ is a government effort in order to overcome the problem of population density, infant mortality and maternal mortality. Family Planning is an attempt to enlarge the child using the use of contraceptives that are beneficial to the Doctor / Midwife. This Family Planning Program to resolve the problem of overcrowding, undesirable infant and maternal mortality known as 4 Too, ie too young, too old, too often pregnant, and too many children. The Government's effort to reduce the birth rate is merely a form of Government to the people who are unable to meet the needs of family life [1].

In ASEAN countries, the average use of contraceptives from 2005-2012 is Thailand's highest at $80 \%$, then Cambodia $79 \%$. In Indonesia, contraceptive use is still below Thailand and Cambodia which is only $61 \%$ [2]. In 2013, active KB coverage in Indonesia is $75.88 \%$. By province, the highest active KB coverage was Bengkulu Province of $87.7 \%$ and the lowest was Papua Province at $67.15 \%$. Banten Province is included in the 3 lowest provinces based on active $\mathrm{KB}$ coverage which is $69.92 \%$ [2].

In addition, the results of the IDHS 2012 indicate that the total fertility rate (TFR) is still at 2.6 where the figure has not decreased over the last ten years, this condition provides an overview of efforts to decrease the rate of population growth through birth control does not go according to which Expected [2].

Basic Health Research Data (Riskesdas) 2013 showed that $49.1 \%$ of married women aged 15-49 years were users of short-term contraceptive methods (injections, pills, condoms, vaginal medications, etc.) and only $10.2 \%$ Long-term contraceptives (IUD, MOW, and Implant) [3].

The results of the Indonesian Demography and Health Surfey (IDHS), 2012 show that 58\% of women of infertile age, locally known as wanita usia subur (WUS), married have used modern contraceptive methods. Injectable contraception is the most widely used method of contraception (32\%), followed by pills (14\%). Injecting FP participants experienced an increase from $12 \%$ in 1991 to $32 \%$ in 2012 , while the use of contraceptive IUD tended to decrease, ie $13.3 \%$ (IDHS 
1991), 10.3\% (IDHS 1997), 6.2\% (IDHS 2002-2003), dropped to $4.9 \%$ (IDHS 2007), and continued to fall again to 3.9\% [4], the low number of IUD users is largely derived from previous studies because the device is installed in the uterus and when Installation with a less pleasant position that makes it lazy and afraid to use it. Viewed from contraceptive service sources, family planning acceptors used private services more than the government $(73 \%$ and $23 \%)$, for $59.8 \%$ of private sector usage and $48.0 \%$ for the IUD [4].

One of the provinces that has a national Long-term contraceptive methods locally known as metode kontrasepsi jangka panjang (MKJP) prevalence is Banten Province which is only $9.8 \%$ [2]. Banten province has 8 districts/cities. South Tangerang is a city that in the year 2013 has a prevalence of $14.5 \%$ MKJP usage that is still below the national target of $26.7 \%$ [2]. In 2014, the population of South Tangerang City is $1,145,939$ people with the number of men as many as 572,728 people and 573,211 inhabitants, consisting of 7 sub-districts 54 sub-sub-district locally known as kelurahan, 260,924 fertile couples, locally known as pasangan usia subur (PUS) with coverage using hormonal contraceptives As much as $45.25 \%$ while non-hormonal contraceptives 24.57, not $29.9 \%$ of family planning participants with MKJP only $21.12 \%$ with a place of getting private family planning as much as $45.25 \%$ and in government services as much as $24.51 \%$, whereas $18.2 \%$ of the IUDs use contraceptives [5]. South Tangerang City is an area that generally includes urban areas can be seen from the various developments in South Tangerang, but in fact rapid development is not in line with the success of family planning programs low IUD use, especially from the 7 subdistricts that exist Setu Sub-district is a region that The lowest attainment of MKJP Contraceptive IUD.

IUD contraception is one long-term method of contraception that can be used for all women of reproductive age after delivery and does not affect breast milk, and can be used up to menopause [6]. The IUD has several advantages over other forms of contraception, because it is non-hormonal contraception, has long-term effectiveness, requires only one installation, does not cause systemic side effects, is more economical, and has high-efficiency and reversible (short-term return of fertility) [7].

\section{METHODS}

The type of research used in this study is quantitative with cross sectional research design.

This research was conducted in Keranggan Publict Health Center unit locally known as Puskesmas, Sub-District of Setu, South Tangerang City. The study was conducted from June to August of 2016.

The large sample calculations were performed using the sample formula for testing the two population hypotheses from Lameshow. The result of sample size with 95\% confidence level and 90\% test strength, the researcher takes the highest sample value (n) with the sample number of 69 active $\mathrm{KB}$ acceptor. Based on the test formula of the proportion of two hypotheses, the number of samples obtained should be multiplied by two of 138 people. To anticipate the occurrence of the drop out, so the authors add $10 \%$ of the sample to 152 people active KB acceptor.

\section{RESULTS}

From table 1 it was found that respondents who did not use IUD more than those using IUD were 138 respondents (90.8\%), and those who used IUD were 14 respondents $(9.2 \%)$. The low utilization of IUD in Puskesmas Keranggan is based on research result because of low education, knowledge and negative attitude about IUD so that the interest to use the contraception is very low. Ignorance about this contraceptive tool resulted in most respondents being afraid to do the installation and from the negative rumors circulating about the IUD.

TABLE I. Distribution FREQUENCY OF RESPONDENTS BASED USE OF THE IUD

\begin{tabular}{|c|c|c|c|}
\hline No. & Use of the IUD & Frequency & Percentage (\%) \\
\hline 1. & Non IUD & 138 & 90,8 \\
\hline 2. & IUD & 14 & 9,2 \\
\hline & Total & 152 & 100 \\
\hline
\end{tabular}

\section{A. Univariate Analysis}

Based on the empirical data obtained the age of the youngest respondent aged 18 years and the oldest age 48 years, obtained an average value of 32.11. Based on table 2, the distribution of respondents by age can be seen that the number of respondents aged $\leq 32.11$ years as many as 82 respondents $(53.9 \%)$ and age $>32,11$ years as many as 70 respondents $(46.1 \%)$.

Educational variables are categorized into two, namely less education and adequate education. Based on Table 2 above, it can be seen that the distribution of respondents according to the level of education that the respondents whose level of education is less as much as 97 respondents $(63.8 \%)$ and the level of education is quite as much as 55 respondents $(36.2 \%)$.

Based on Table 2, respondents who did not work there were 47 respondents $(30.9 \%)$, while respondents who worked as many as 105 respondents $(69.1 \%)$. Respondents who were Labor/Farmers/Industries were 28 respondents (18.4\%), entrepreneurs/traders 21 respondents (13.8\%), private employees 13 respondents (8.6\%) and others 44 (28.9\%). From table 2, respondents whose economic status is $\leq$ Regional Basic Salary, locally known as UMR is $104(68.4 \%)$, and the economic status > UMR is 48 respondents $(31.6 \%)$. 
TABLE II. ChaRACTERISTICS OF RESPONDENTS AgE, EdUCATION, Job

\begin{tabular}{|c|c|c|}
\hline Variable & Frequency & Percentage (\%) \\
\hline Age & 82 & 5.9 \\
$\leq 32,11$ & 70 & 46.1 \\
$>32,11$ & 152 & 100 \\
Total & & \\
& & \\
\hline Education & & \\
1.Less & 97 & 63.8 \\
2.Adequate & 55 & 36.2 \\
Total & 152 & 100 \\
& & \\
\hline Job & & \\
1.Does'nt Work & 47 & 30.9 \\
2.Work & 105 & 69.1 \\
Total & 152 & 100 \\
& & \\
\hline Economic status & & \\
1 104 UMR & 48 & 68.4 \\
2.> UMR & 152 & 100 \\
Total & & \\
& & \\
\hline
\end{tabular}

Based on the empirical data, the respondent has at least 1 child and has at most 5 children, so that the average value is 2.06. Furthermore, categorized into 2, respondents who have the number of children living between 0-2 are classified in the small category that is as many as 115 respondents $(74.3 \%)$. Meanwhile, respondents who have children $\geq 3$ are categorized into many categories, there are 37 respondents $(24.3 \%)$.

From Table 3, it is known that respondents who do not want to add children are 80 respondents (52.6\%), and who have the desire to add 72 respondents $(47.4 \%)$.

From table 4, it is known that respondents whose knowledge is less as much as $78(51.3 \%)$ and respondents are good knowledge 74 (48.7\%).

From table 5, it is known that respondents who have negative attitude are $78(49.3 \%)$ and have positive attitude 74 respondents $(50.7 \%)$.

TABLE III. DistRIBUtIon FREQUENCY OF RESPONDENTS By NUMBER OF LIVING CHILDREN AND THE DESIRE OF ADDING CHILDREN.

\begin{tabular}{|c|c|c|}
\hline Variable & Frequency & Percentage (\%) \\
\hline Number of Living & & \\
Children & & \\
Little & 115 & 74.3 \\
Many & 37 & 24.3 \\
Total & 152 & 100 \\
\hline Desire of Adding & & \\
Children & 80 & 52.6 \\
1.No & 72 & 47.4 \\
2.Yes & 152 & 100 \\
Total & & \\
& & \\
\hline
\end{tabular}

TABLE IV. Distribution Frequency of Respondents BASEd on KNOWLEDGE

\begin{tabular}{|c|c|c|c|}
\hline No. & Knowledge & Frequency & Percentage (\%) \\
\hline 1 & Less & 78 & 51.3 \\
\hline 2 & Good & 74 & 48.7 \\
\hline & Total & 152 & 100 \\
\hline
\end{tabular}

TABLE V. Distribution FReQuency of ResPondents BASED ON ATTITUDE

\begin{tabular}{|c|c|c|c|}
\hline No. & Attitude & Frequency & Percentage (\%) \\
\hline 1 & Negative & 78 & 51.3 \\
\hline 2 & Positive & 74 & 48.7 \\
\hline & Total & 152 & 100 \\
\hline
\end{tabular}

TABLE VI. Distribution FREQUENCY OF RESPONDENTS BASED ON HUSBAND SUPPORT

\begin{tabular}{|c|c|c|c|}
\hline No. & $\begin{array}{c}\text { Husband } \\
\text { Support }\end{array}$ & Frequency & Percentage (\%) \\
\hline 1 & $\begin{array}{c}\text { Quite } \\
\text { Supportive }\end{array}$ & 63 & 41.4 \\
\hline 2 & $\begin{array}{c}\text { Very } \\
\text { Supportive }\end{array}$ & 89 & 58.6 \\
\hline & Total & 152 & 100 \\
\hline
\end{tabular}

Based on Table 6. It is known that respondents who get enough support from husband as much as 63 respondents (41.4\%), and the majority of 89 respondents feel strongly supported by husband (58.6\%)

\section{B. Bivariate Analysis}

TABLE VII. DISTRIBUTION RELATIONSHIP OF RESPONDENTS AGE WITH IUD USE ON WOMEN ACCEPTORS KB IN UPT AREA OF PUSKESMAS KERANGGAN SETU SUB-DISTRICT OF TANGSEL CITY YEAR 2016

\begin{tabular}{|c|c|c|c|c|c|c|c|c|}
\hline \multirow{3}{*}{ Age } & \multicolumn{4}{|c|}{ Contraception } & \multicolumn{2}{c|}{ Total } & \multirow{2}{*}{$\begin{array}{c}\text { OR } \\
(95 \% \mathrm{CI})\end{array}$} & \multirow{2}{*}{ Value } \\
\cline { 2 - 6 } & \multicolumn{2}{|c|}{ No IUD } & \multicolumn{2}{|c|}{ IUD } & \multicolumn{2}{|c|}{} \\
\cline { 2 - 7 } & $\mathrm{N}$ & $\%$ & $\mathrm{~N}$ & $\%$ & $\mathrm{~N}$ & $\%$ & & \\
\hline$\leq 32.11$ & 77 & 93.9 & 5 & 6.1 & 82 & 53.9 & 2.272 & 0.248 \\
\hline$>32.11$ & 61 & 87.1 & 9 & 12.9 & 70 & 46.1 & $(0.72-7.13)$ & \\
\hline TOTAL & 138 & 90.8 & 14 & 9.2 & 152 & 100 & & \\
\hline
\end{tabular}

TABLE VIII. Distribution RELATIONSHIP OF RESPONDENTS AGE WITH IUD USE ON WOMEN ACCEPTORS KB IN UPT AREA OF PUSKESMAS KeRANGGAN SETU SUB-DISTRICT OF TANGSEL City YeAR 2016

\begin{tabular}{|c|c|c|c|c|c|c|c|c|}
\hline \multirow[t]{3}{*}{ Education } & & \multicolumn{3}{|c|}{ Contraception } & \multirow{2}{*}{\multicolumn{2}{|c|}{ Total }} & \multirow{3}{*}{$\begin{array}{c}\mathrm{OR} \\
(95 \% \mathrm{CI})\end{array}$} & \multirow{3}{*}{$\begin{array}{c}\mathrm{P} \\
\text { Value }\end{array}$} \\
\hline & \multicolumn{2}{|c|}{ No IUD } & \multicolumn{2}{|c|}{ IUD } & & & & \\
\hline & $\mathrm{N}$ & $\%$ & $\mathrm{~N}$ & $\%$ & $\mathrm{~N}$ & $\%$ & & \\
\hline LESS & 92 & 94.8 & 5 & 5.2 & 97 & 63.8 & 3.600 & 0.045 \\
\hline ADUQUATE & 46 & 83.6 & 9 & 16.4 & 55 & 36.2 & $\begin{array}{l}(1.141- \\
11.359)\end{array}$ & \\
\hline TOTAL & 138 & 90.8 & 14 & 9.2 & 152 & 100 & & \\
\hline
\end{tabular}


TABLE IX. DISTRIBUTION RELATIONSHIP OF KNOWLEDGE LEVEL RESPONDENTS' WITH IUD USE ON WOMEN ACCEPTORS KB IN UPT DISTRICT Puskesmas KeRANGgan SETU Sub-District TANGSEl City 2016

\begin{tabular}{|c|c|c|c|c|c|c|c|c|}
\hline \multirow[t]{3}{*}{ Knowladge } & \multicolumn{4}{|c|}{ Contraception } & \multirow{2}{*}{\multicolumn{2}{|c|}{ Total }} & \multirow{3}{*}{$\begin{array}{c}\mathrm{OR} \\
(95 \% \mathrm{CI})\end{array}$} & \multirow{3}{*}{$\begin{array}{c}\mathrm{P} \\
\text { Value }\end{array}$} \\
\hline & \multicolumn{2}{|c|}{ No IUD } & \multicolumn{2}{|c|}{ IUD } & & & & \\
\hline & $\mathrm{N}$ & $\%$ & $\mathrm{~N}$ & $\%$ & $\mathrm{~N}$ & $\%$ & & \\
\hline LESS & 78 & 100 & 0 & 0 & 78 & 51.3 & 3.769 & 0.000 \\
\hline GoOD & 60 & 81.1 & 14 & 18.9 & 74 & 48.7 & & \\
\hline TOTAL & 138 & 90.8 & 14 & 9.2 & 152 & 100 & & \\
\hline
\end{tabular}

TABLE X. DISTRIBUTION RELATIONSHIP OF RESPONDENTS' ATTITUDES WITH IUD USE ON WOMEN ACCEPTORS KB IN UPT AREA OF PUSKESMAS KERANGGAN SETU SUB-DISTRICT OF TANGSEL CITY YEAR 2016

\begin{tabular}{|l|c|c|c|c|c|c|c|c|}
\hline \multirow{2}{*}{ Attitude } & \multicolumn{4}{|c|}{ Contraception } & \multicolumn{2}{c|}{ Total } & \multirow{2}{*}{$\begin{array}{c}\text { OR } \\
(95 \% \mathrm{CI})\end{array}$} & $\begin{array}{c}\mathrm{P} \\
\text { Value }\end{array}$ \\
\cline { 2 - 7 } & $\mathrm{N}$ No IUD & \multicolumn{2}{|c|}{ IUD } & \multicolumn{2}{|c|}{} \\
\cline { 2 - 7 } & $\mathrm{N}$ & $\%$ & $\mathrm{~N}$ & $\%$ & $\mathrm{~N}$ & $\%$ & & \\
\hline NEGATIVE & 76 & 97.4 & 2 & 2.6 & 78 & 51.3 & 7.355 & 0.009 \\
\hline PosITIVE & 62 & 83.7 & 12 & 16.2 & 74 & 48.7 & $\begin{array}{c}(1.586- \\
34.104)\end{array}$ & \\
\hline TOTAL & 138 & 90.8 & 14 & 9.2 & 152 & 100 & & \\
\hline
\end{tabular}

TABLE XI. Multivariate Analysis Result Using Logistic REGRESSION METHOD ENTER

\begin{tabular}{|c|c|c|c|c|c|c|}
\hline \multirow[t]{2}{*}{ VARIABLE } & \multirow[t]{2}{*}{ B } & \multirow[t]{2}{*}{ S.E } & \multirow[t]{2}{*}{$\begin{array}{c}\mathrm{P} \\
\text { VALUE }\end{array}$} & \multirow[t]{2}{*}{ OR } & \multicolumn{2}{|c|}{$\begin{array}{c}\text { 95\% C.I.FOR } \\
\text { EXP(B) }\end{array}$} \\
\hline & & & & & LOWER & $\begin{array}{c}\text { UPPE } \\
\mathrm{R}\end{array}$ \\
\hline AGE & 0.103 & 0.051 & 0.004 & 1.106 & 1.003 & 1.225 \\
\hline EDUCATION & 0.885 & 0.496 & 0.074 & 2.422 & 0.916 & 6.404 \\
\hline KNOWLEDGE & 19.143 & $\begin{array}{r}4134 . \\
837 \\
\end{array}$ & 0.996 & $2.060 \mathrm{E} 8$ & 0.000 & \\
\hline ATTITUDE & 1.799 & 0.834 & 0.031 & 6.042 & 1.179 & $\begin{array}{r}30.95 \\
1\end{array}$ \\
\hline
\end{tabular}

The result of statistical analysis showed in Table VII that there was no correlation between IUD and non-IUD contraception type selection with respondent age $(p>0.05)$. It appears that the use of non-IUD contraceptives was almost the same in $\leq 32.11$ years old $(94.9 \%)$ with age $>32.11$ years $(87.1 \%)$.

The result of statistical analysis showed in table VIII that there was a correlation between the selection of contraceptive type IUD and non-IUD with the respondent's education level ( $p$ $<0,05)$. It appears that non-IUD users are more likely to have lower educated respondents $(94.8 \%)$ than those with sufficient education $(83.6 \%)$.

The result of statistical analysis showed that there was a correlation between the selection of contraceptive type IUD and non-IUD with knowledge of respondent ( $p<0.05)$. It is seen that the use of non-IUD is more in the respondents whose knowledge is less $(100 \%)$ than the respondents have good knowledge (81.1\%).

The result of statistical analysis shows in table $\mathrm{X}$ that there is a correlation between the selection of contraceptive type IUD and non-IUD with respondent attitude ( $p>0.05)$. It shows that non-IUD usage is more negative (97.4\%) than respondents who are positive $(83.7 \%)$.

The final result of analysis got the greatest OR value of 6,042 that is attitude variable, meaning that respondent have negative attitude $6 \mathrm{x}$ bigger chance not to use contraception IUD after controlled variable age, education, and knowledge and there are 2 variable confounding that is knowledge and education variable. So it can be concluded that influential variables are age and attitude. And the variable that is more influential or the most dominant to the use of contraceptive IUD is the attitude variable.

\section{CONCLUSION}

This research yields several conclusions such as:

1. Active $\mathrm{KB}$ acceptor using IUD contraceptives is $9.2 \%$.

2. There is a significant relationship between education,

knowledge and attitude with the use of the IUD.

The most dominant factor influencing the use of IUD in the area of Puskesmas Keranggan Setu District in 2016 is the attitude with the acquisition value of OR 6,024 means that respondents with negative attitude will tend to 6 times the opportunity to not use IUD than respondents who have a positive attitude.

\section{REFERENCES}

[1] BKKBN, Program KB di Indonesia. 2008. Retrive from http://www.bkkbn.go.id

[2] BKKBN, Panduan Akselerasi Pembangunan KKB Tahun 2013 2014 dalam Rangka Pencapaian Target MDGs Tahun 2015. Jakarta, 2013

[3] Depkes RI. Riset Kesehatan Dasar 2010. Jakarta: Departemen Kesehatan Republik Indonesia, 2013.

[4] BPS, BKKBN, Kemenkes RI dan Marco International. Survey Demografi dan Kesehatan Indonesia Jakarta: BPS, BKKBN, Kemenkes RI dan Macro International, 2012.

[5] BPMPPKB Kota Tangerang Selatan, Laporan Tahunan Kependudukan Kota Tangerang Selatan, 2015.

[6] Saifuddin, Ilmu Kebidanan. Jakarta: yayasan Bina Pustaka Sarwono Prawihardjo, 2008.

[7] BKKBN dan Diktorat Bina Kesehatan Ibu.. Pedoman PelayananKeluarga Berencana Pasca Persalinan di Fasilita s Kesehatan. Jakarta: Kementrian Kesehatan RI, 2012. 